between trading and professionalism, temporarily came down on the wrong side of the fence, being united with the Grocers Company by charter in 1606 . But this inconvenient marriage was dissolved in 1617 , when the Society of Apothecaries obtained its own charter, James I saying that the apothecaries practised an art as well as a mystery, whereas the grocers were merely merchants.

THe apothecaries used their new freedom for still further specialization. They enhanced their reputation by devotion to the sick at the time of the Great Plague and rapidly developed into the general practitioners of medicine, a position ultimately recognized by registration under the Medical Act. They gradually abandoned pharmacy for physic and left the way open for the pharmacist as he is known to-day to take their place. Sir Humphry Rolleston did not follow the progress of specialization in recent years. Had he done so he might have shown how to-day, with the progress of medical science, specialization advances apace in both the medical and the pharmaceutical professions. In medicine, the physician and the surgeon find at their elbow the bacteriologist, the pathologist, the radiologist, the psycho-therapist. In pharmacy, the pharmacologist, the biochemist and the serologist are supplanting the galenical pharmacist. It is well for the patient, for whose benefit alone these 'mechanized troops' take the field, that so far they remain auxiliaries and have not yet displaced the 'private of the line'-the general practitioner and the pharmacist at the corner of the road.

\section{Flints and Flint-Working}

A sPECIAL exhibition to remain for three months has been arranged at the British Museum, Bloomsbury, at the head of the main staircase, to illustrate the changes in flint, and the various methods of chipping it into implements. This supplements the permanent series in the Prehistoric Saloon (Case R), and is intended to make the grammar of the subject doar to those with restricted opportunities of observing or collecting specimens. Patina has not yet been scientifically explained, but the examination of its varieties is a necessary step in solving the problem, and attention has been paid to the depths attamed by patina on several specimens. Some old pieces have been re-chipped by living practitioners; and among those whose skill is exemplified may be mentioned Mr. J. Reid Moir, Mr. J. H. Sewell of Saskatoon, M. Coutier of Paris and Prof. A. S. Barnes. Some peculiar forms assumed by flints when fractured by man or natural forces are exhibited, and the technical terms used in prehistory are illustrated by typical specimens. Drawings of flaking methods presumably practised in the Stone Age are reproduced from Warren K. Moorehead's "Stone Age in North America", and a special feature is the wood-technique (blows delivered by a wooden baton) which is believed to have been adopted by St. Acheul man, the long narrow flake-scars due to this method helping to distinguish work of that date from the preceding Chelles or Abbeville culture.

\section{Origins of Civilization and the Hittites}

THE early history of Anatolia and of the races from which the Turkish people is held to be derived was given due prominence in the communications presented by the numerous foreign members attending the second session of the Historical Congress at Istamboul. In particular, it is stated by the correspondent of The Observer in the issue of October 11, much importance was attached to a discussion by Prof. E. Pittard of Geneva of the origin of the early brachycephalic racial type, which, first appearing in Europe in the Mesolithic age, introduced to that continent the domestication of animals and agriculture. He pointed out that nowhere except in the Near East and in the region extending eastwards to Afghanistan were cereals to be found growing in the original wild state, while the same habitat was assigned to the wild prototypes of the domesticated animals. Prof. Pittard then went on to show that a close study of the Hittites indicated that all these elements of civilization were well known to them from early times, this leading to the supposition that we are indebted to this people for their evolution. Recent discoveries and excavations indicate a possibility of demonstrating that Anatolia possessed, just like Europe, a palæolithic period, from which the mesolithic was evolved, and that the remotest origins of civilization may be found in Anatolia. As the views put forward by Prof. Pittard are said to coincide with the point of view of the Turkish Society for Historical Research, it is possible that they will stimulate muchneeded intensive study of Hittite origins. It is eminently desirable, however, that this should be extended to include the Caucasus regions to the north of the Hittite area, with which certain of the evidence, especially of philology, appears to indicate a cultural affinity.

\section{Maiden Castle, Dorchester}

Two discoveries are announced at the close of the season's excavation of Maiden Castle, Dorchester, by the Society of Antiquaries and the Dorset Natural History and Archæological Society under Dr. R. E. Mortimer Wheeler and Col. C. D. Drew. The first is that of a long barrow of remarkable size, no less than eight hundred feet long, overlying the neolithic town, of which the remains have been identified at various points in the eastern part of the site. Evidently the village must wholly, or largely, have ceased to be occupied when this enormous tomb was constructed. Consequently, as is pointed out by Dr. Wheeler, according to a report in The Times of October 11, the discovery is of importance. The superposition of the neolithic barrow over the earlier neolithic town will make it possible to classify the successive phases of neolithic civilization in this part of Britain with greater precision than is possible at present, and it will thus afford a standard of chronological comparison for the interpretation of other neolithic settlements and mounds in this part of the country. The second discovery, which was made not far from the point at which the dismembered neolithic skeleton, previously reported, was found, was that 